\title{
Analisis Pengeluaran dan Tingkat Kesejahteraan Rumahtangga Petani Karet Di Kecamatan Karang Jaya Kabupaten Musi Rawas Utara
}

\section{Household Expenditure Analysis and Economic Welbeing of Rubber Farmers In Karang Jaya District, Musi Rawas Regency, South Sumatra}

\section{May Shiska Puspitasari* Dan Ira Primalasari}

*)Program Studi Agribisnis Fakultas Pertanian Universitas Musi Rawas

E-mail : mayshiska@unmura.ac.id

\section{ABSTRACT}

\begin{abstract}
This study aimed (1) to measure rubber tappers'household expenditure, (2) to investigate factorswhich affect to the rubber tappers'household expenditure, and (3) to analyzethe wealthy level of rubber tappers'household in Karang Jayasub-districtby using descriptive analysis and multiple linier regression analysis. The samples were 95respondents taken by using survey method. Moreover, the result of the study explained that rubber tappers'household expenditure in Karang Jaya, consist of carbohydrate (44,60\%), noncarbohydrate (25,06\%), and non-food (30,34\%). The carbohydrate expenditure is the highest percentage among others. Wealthy level of this study uses 14 variables; types of wooden wall $(35,7 \%)$, wells water resources $(70,53)$, firewood recourses $(22,11)$, river sanitation facility (26,32), types of tile floor/cement $(68,42)$, primary education (54), light source of PLN $(98,95)$, car asset $(8,42)$, motorcycle $(85,26)$, Polindes $(66,54)$, floor space $8 m 2(58,87)$, wear per year (46,27) (1-2) per day (19,23), and incomeRp. 600.000/month (53, 69). Furthermore, factors which affect to the rubber tappers'household expenditure in Karang Jaya are the number of family memberand income which explain $F$ value $(141,56)>F$ table $(2,47)$. Therefore, it can be concluded that education, age, income, family numberand space positively and significantly affect to the rubber tappers'household expenditure in Karang Jaya. Rvalue square is 0,888, and explains that 88\% household expenditure can be explained by age, education, family number, space, and income, while 12\%is measured by other variables. Carbohydrate 44,25\% is higher than non-carbohydrate and non-food, thus household in Karang Jaya has not been wealthy yet.
\end{abstract}

Keywords: Household expenditurer, rubber farmers, economic welbeing

Disubmit : 7 Februari 2021; Diterima: 20 Februari 2021; Disetujui : 28 April 2021

\section{PENDAHULUAN}

Perkebunan tanaman karet merupakan salah salah satu peranan yang penting dalam menunjang perekonomian negara. Hal ini dikarenakan penyebaran dan pengusahaan tanaman karet yang cukup besar dan telah tersebar di berbagai wilayah Indonesia. Salah satunya yaitu di Provinsi Sumatera Selatan yang memiliki produksi karet sebagaisumber penghasilan masyarakat di pedesaan. Berdasarkan data (Statistik, 2020) memiliki luas areal perkebunan karet sebesar 1.305.699 Ha dengan jumlah produksi karet sebesar 905.789 ton. Jumlah produksi karet ini menurun dari jumlah sebesar 1 persen. Hal ini disebabkan kualitas tanaman karet yang rendah. Peran komoditas tanaman karet ini sangat cukup berarti dalam perekonomian di Provinsi 
Sumatera Selatan, walaupun perannya terhadap peningkatan kesejahteraan petani masih belum signifikan terutama di Kabupaten Musi Rawas Utara.

Komoditas karet menjadi sumber pendapatan bagi masyarakat di Kabupaten Musi Rawas Utara dalam memenuhi kebutuhan hidup. Menurut (Statistik, 2019), tingkat pendapatan dalam rumahtangga mempengaruhi pola pengeluaran yang dikeluarkan. Menurut (Supriadi et al., 2010), berdasarkan hasil penelitiannya di Kabupaten Musi Banyu Asin, menyatakan bahwa sebagian besar pengeluaran rumahtangga petani karet digunakan untuk kebutuhan pokok/pangan sebesar (82-83\%). Pendapatan untuk pemeliharaan kebun yang rendah ini dipengaruhi oleh rendahnya pengeluaran. Pengeluaran rumahtangga petani menurut "Hukum Engel" yaitu semakin rendah pendapatan seseorang maka semakin besar jumlah pengeluaran yang dikeluarkan untuk konsumsi pangan (Jannah, 2018).

Kecamatan Karang Jaya merupakan salah satu Kecamatan yang ada di Kabupaten Musi Rawas Utara dengan luas lahan perkebunan karet sebesar $41.576 \mathrm{Ha}$ atau sebesar 22 persen terhadap total luas lahan perkebunan karet di Kabupaten Musi Rawas Utara. Kecamatan Karang Jaya memiliki jumlah produksi karet tertinggi dari Kecamatan lain yaitu sebesar 32.714 ton/tahun (Statistik, 2019). Masyarakat di Kecamatan Karang Jayamengusahakan tanaman karet sebagai sumber penghasilan utama dalam memenuhi kebutuhan hidupnya, sehingga karet merupakan faktor penentu dalam meningkatkan pendapatan rumahtangga yang merupakan unit terkecil dalam masyarakat yang terdiri dari suami, istri, anak dan anggota keluarga lain yang tinggal dalam satu keluarga. Tingkat pendapatan yang diterima oleh petani karet akan mempengaruhi jumlah pengeluaran yang dikeluarkan dalam rumahtangga untuk memenuhi kebutuhan. Semakin besar pendapatan yang diterima seorang rumahtangga maka semakin besar pengeluaran yang dikeluarkan begitu juga sebaliknya. Namun tidak semua rumahtangga memiliki konsep yang sama tentang pengeluaran yang dikeluarkan berdasarkan pendapatan yang diterima. Ada juga rumahtangga yang memiliki pendapatan lebih tinggi namun pengeluaran yang dikeluarkan hanya sedikit. Pada umumnya pengeluaran rumahtangga yaitu pengeluaran pangan (karbohidrat dan non karbohidrat) dan non pangan, hal ini berkaitan juga dengan tingkat kesejahteraan rumahtangga. Apabila semakin besar jumlah pengeluaran pangan dalam rumahtangga maka hal ini dikatakan bahwa rumahtangga tersebut belum sejahtera. Namun sebaliknya jika pengeluaran non pangan lebih besar maka dikatakan bahwa rumahtangga tersebut dikatakan sejahtera.

Menurut Eliza, Khaswarina dan Nasution (2014), menyatakan bahwa tingkat kesejahteraan masyarakat dapat dilihat dalam pengeluaran yang digunakan untuk makanan, apabila pengeluaran untuk makanan lebih besar maka menunjukkan semakin rendahnya tingkat kesejahteraan masyarakat. Begitu juga dengan BPS yang mengukur kesejahteraan keluarga dengan menggunakan pengeluaran per kapita per bulan, dimana pengeluaran dalam rumahtangga merupakan cerminan konsumsi keluarga dalam mencukupi kebutuhan pangan dan non pangan (Elmanora et al., 2012).

Penghasilan rumahtangga petani karet yang bersumber dari usahatani karet maupun dari non usahatani akan menentukan seberapa besar pengeluaran dan tingkat kesejahteraan rumahtangga petani karet. Berlatar Belakang uraian di atas, permaslaahan yang menarik untuk diteliti mengenai "Analisis Pengeluaran dan Tingkat Kesejahteraan Rumahtangga Petani Karet Di Kecamatan Karang Jaya”.

\section{METODE PENELITIAN}

\section{Metode Penentuan Lokasi}

Lokasi penelitian dilakukan di Kecamatan Karang JayaKabupaten Musi Rawas Utara. Lokasi penelitian ditentukan secara sengaja (purposive) hal ini dikarenakan mayoritas masyarakat di Kecamatan tersebut menggantungkan hidupnya dengan berusahatani karet, sehingga menjadi dasar pertimbangan dalam menentukan lokasi penelitian. 
May Shiska Puspita Sari \& Ira, P.: Analisis Pengeluaran dan Tingkat Kesejahteraan Rumah Tangga Petani....

\section{Metode Penarikan Sampel dan Sumber Data}

Pengambilan sampel menggunakan metode survey dan penarikan sampel dengan metode acak sederhana (simple random sampling). Di Kecamatan Karang Jaya terdiri dari 15 Desa, dimana diambil secara purposive sebanyak 3 desa sebagai sampel dalam penelitian dengan pertimbangan desa yang mayoritas masyarakatnya berusahatani karet. Jumlah responden yang diambil dalam penelitian disajikan pada Tabel dibawah ini.

Tabel 1. Penarikan Sampel Penelitian di Kecamatan Karang Jaya

\begin{tabular}{cllll}
\hline No & Nama Desa & $\begin{array}{l}\text { Jumlah } \\
\text { Populasi }\end{array}$ & Proporsi (\%) & Jumlah Sampel \\
\hline 1 & Bukit Langkap & 252 & 10 & 25 \\
2 & Karang Jaya & 351 & 10 & 35 \\
4 & Sukaraja & 347 & 10 & 35 \\
\hline Jumlah & & & 95 \\
\hline
\end{tabular}

Data primer diperoleh melalui wawancara langsung dengan petani karet yang menggunakan pertanyaan atau kesioner yang telah disusun dan data sekunder bersumber dari literatur/referensi buku, internet, data dinas dan data sekunder lain yang berkaitan dengan topik penelitian

\section{Metode Analisis Data}

Data penelitian ini akan dianalisis dengan menghitung besarnya pengeluaran rata-rata rumahtangga petani karet. Untuk menjawab tujuan yang pertama yaitu dengan menghitung pengeluaran rumahtangga yang terdiri dari pengeluaran pangan dan non pangan. Untuk menjawab tujuan kedua dalam penelitian ini yaitu dengan menggunakan analisis regresi linier berganda. Variabel yang diteliti untuk mengetahui faktor-faktor yang diduga mempengaruhi pengeluaran rumahtangga petani karet yaitu pendidikan, umur, pendapatan, Jumlah anggota keluarga dan luas lahan

Model regresi yang digunakan untuk menjelaskan faktor-faktor yang mempengaruhi pengeluaran rumahtangga disajikan pada model sebagai berikut:

$$
Y=\beta o+\beta_{1} X_{1}+\beta_{2} X_{2}+\beta_{3} X_{3}+\beta_{4} X_{4}+\beta_{5} X_{5}+e
$$

Keterangan :

Y : Pengeluaran

Bo : Konstanta

$\beta_{1 \ldots . . .} \beta \mathrm{n}$ : Koefisien Regresi

$\mathrm{X} 1$ : Pendidikan

X2 : Umur

X3 : Pendapatan

X4 : Jumlah Anggota Keluarga

X5 : Luas lahan

e : Standar error

Pada penelitian ini parameter (pendidikan, umur, pendapatan, Jumlah anggota keluarga dan luas lahan) diuji dengan menggunakan regresi secara tunggal maupun bersama-sama. Parameter yang diuji secara tunggal dapat dilakukan dengan menggunakan uji $\mathrm{t}$, danuntuk menguji secara bersama-sama digunakan uji $\mathrm{F}$ serta melihat tingkat signifikansi yang dihasilkan.

Untuk menjawab tujuan penelitian yang ketiga menggunakan analisis data berdasarkan kriteria masyarakat sejahtera. Pada penelitian ini, 14 variabel yang diteliti berdasarkan kriteria (Statistik, 2005) yaitu jenis dinding, sumber air minum, bahan bakar yang digunakan, fasilitas sanitasi, jenis lantai, pendidikan, 
sumber penerangan, kepemilikan aset, tempat berobat, luas lantai, konsumsi daging/ayam/susu, pakaian, makan dan pendapatan.

\section{HASIL DAN PEMBAHASAN Karakteristik Responden}

Rata-rata umur petani karet di Kecamatan Karang Jaya berkisar antara 44 tahun yang artinya bahwa petani karet di wilayah penelitian berada pada usia produktif sehingga dalam hal ini petani cukup berpotensi dalam mengelola usahataninya. Pendidikan tertinggi di Kecamatan Karang Jaya yaitu pada Sekolah Menengah Atas (SMA), yaitu sebanyak 32 petani. Hal ini menunjukkan bahwa tingkat pendidikan di Kecamatan Karang Jaya sudah baik, karena sebagian besar petani telah menyelesaikan pendidikan di atas wajib belajar 9 tahun. Menurut (Fatimah \& Syamsiyah, 2018), seseorang yang memiliki tingkat pendidikan yang baik dapat meningkatkan pengetahuan dan wawasan seseorang, selain itu juga akan mempengaruhi pola berpikir dalam memecahkan suatu persoalan yang ada dalam kehidupan. Berkaitan dengan pengeluaran di suatu rumah tangga, pendidikan juga akan mempengaruhi pengambilan keputusan dalam pengeluaran konsumsi pangan dalam suatu rumahtangga. Hasil penelitian serupa dari (Sugesti et al., 2015), menyatakan bahwa pendidikan petani akan berpengaruh terhadap pengeluaran dalam rumahtangga. Hasil penelitian yang sejenis (Illahi et al., 2018), menyatakan bahwa seseorang yang memiliki pendidikan yang tinggi tidak hanya mempengaruhi pengeluaran konsumsi saja, namun juga kebutuhan informasi dan pergaulan, sehingga pendidikan yang tinggi seseorang dapat meningkatkan kesejahteraan dalam rumahtangga. Pengalaman dalam berusahatani di Kecamatan Karang Jaya memiliki rata-rata pengalaman selama 16 tahun, yang berarti bahwa para petani di Kecamatan Karang Jaya telah memiliki pengalaman yang cukup lama dalam melakukan usahataninya. Lamanya tingkat pengalaman seorang petani dalam mengelola usahataninya, akan mempengaruhi kinerja dan hasil yang diperolehnya. Menurut (Jannah, 2018), semakin lama pengalaman seseorang dalam berusahatani, maka petani akan lebih cakap dan terampil dalam mengelola usahataninya. Karakteristik selanjutnya yaitu jumlah anggota keluarga. Jumah anggota rumahtangga petani karet di Kecamatan Karang Jaya dengan kisaran antara 1-7 orang dan rata-rata 3 orang per rumahtangga. Menurut (Sugesti et al., 2015), jumlah tanggungan anggota keluarga dalam suatu rumahtangga akan berpengaruh terhadap pengeluaran rumah tangga, yang artinya bahwa jika jumlah anggota keluarga banyak, maka pengeluaran untuk keperluan rumahtangga akan naik, begitu juga sebaliknya jika jumlah tanggungan anggota keluarga sedikit, maka pengeluaran untuk kebutuhan hidup dalam rumahtangga juga sedikit.

\section{Pengeluran Rumahtangga Petani Karet}

Konsumsi rumahtangga merupakan pengeluaran rumahtangga yang dikeluarkan untuk pengeluaran makanan dan non makanan. Pengeluaran makanan terdiri dari pengeluaran karbohidrat dan non karbohidrat. Berikut rincian masing-masing pengeluaran rumahtangga petani karet:

a. Pengeluaran Karbohidrat

Pengeluaran pangan karbohidrat terdiri dalam penelitian terdiri dari beras, jagung, umbi-umbian, singkong, sagu dan gandum. Karbohidrat merupakan sumber makanan utama bagi manusia. Berikut ini proporsi konsumsi untuk pengeluaran karbohidrat dari berbagai sumber makanan: 


\section{Pengeluaran Karbohidrat}

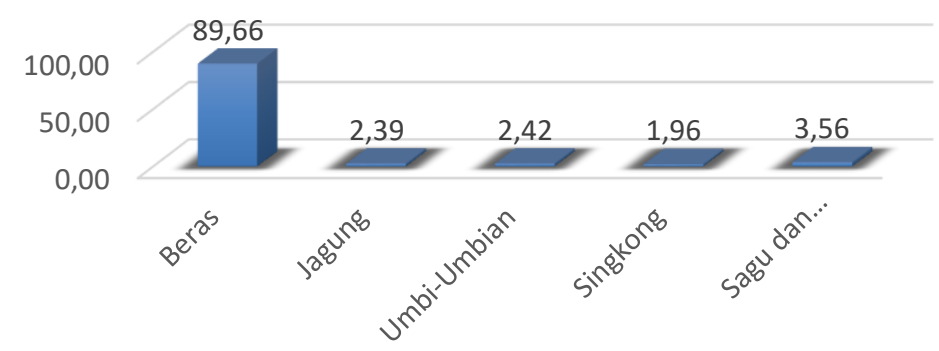

Gambar 1. Proporsi setiap jenis pengeluaran karbohidrat

Berdasarkan gambar 1 di atas, menunjukkan bahwa pengeluaran tertinggi responden petani karet di Kecamatan Karang Jaya yaitu pengeluaran untuk beras sebesar $89,66 \%$ dari total pengeluaran pangan karbohidrat, kemudian pengeluaran tertinggi kedua diikuti dengan pengeluaran sagu dan gandum sebesar 3,56\%, umbi-umbian 2,42\%, jagung 2,39\%, dan singkong 1,96\%. Hal ini berarti bahwa masyarakat di Kecamatan Karang Jaya sebagian besar masih mengkonsumsi beras yang diolah menjadi nasi sebagai makanan sumber karbohirat. Belum ada inovasi ataupun makanan pengganti sumber karbohidrat yang lain. Hasil penelitian ini didukung oleh penelitian (Hasibuan, 2016) dimana rata-rata pengeluaran untuk beras memiliki pengeluaran terbesar dari pengeluaran yang lain, yang berarti bahwa rata-rata kebutuhan rumahtangga petani karet belum maju. Hal ini dikarenakan sebagian besar pendapatan yang diperoleh di gunakan untuk membeli kebutuhan pokok yaitu beras, sementara sumber karbohidrat yang lain belum diutamakan. Hasil penelitian serupa oleh (Kencana et al., 2014) yang memiliki persentase tertinggi sebesar 85,12\% dalam konsumsi beras dibandingkan dengan sumber karbohidrat yang lain seperti beras ketan, tepung terigu dan tepung beras. Hal ini dikatakan wajar karena beras merupakan makanan pokok yang dikonsumsi setiap harinya oleh masyarakat dibandingkan dengan sumber karbohidrat yang lain, untuk itu tingkat konsumsi pangan karbohidrat sangat dominan dalam kebutuhan pangan masyarakat. Hasil Selanjutnya yaitu pengeluaran non karbohidrat disajikan pada Gambar 2.

b. Pengeluaran Non Karbohidrat

Pengeluaran non karbohidrat yang dalam penelitian ini terdiri dari daging, ayam, telur, ikan, kacang tanah, kacang kedeai, tahu, tempe, sayuran, buah-buahan, minyak, bumbu dan rokok.

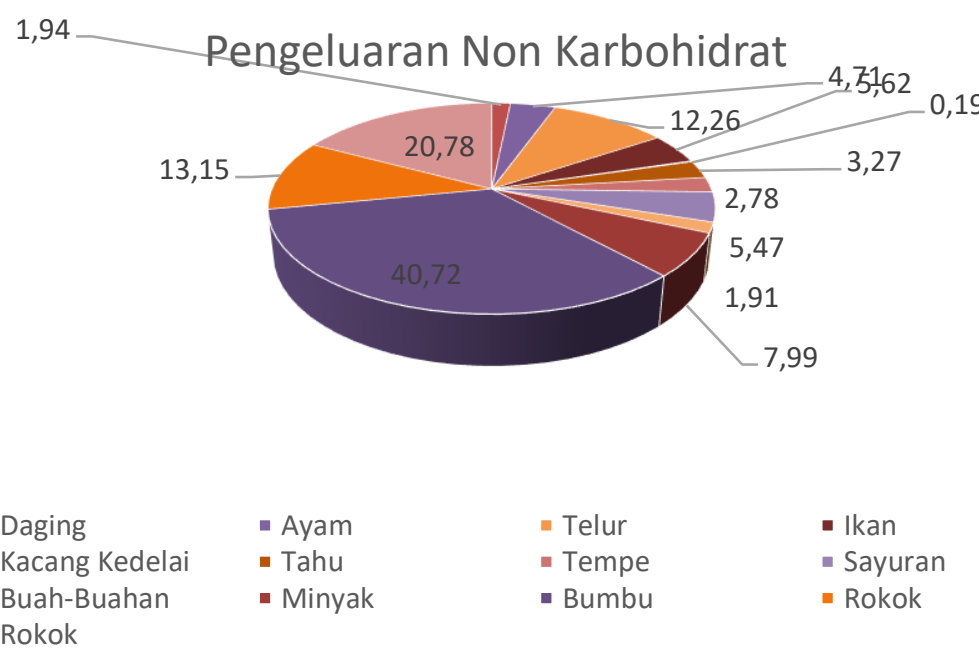

Gambar 2. Proporsi pengeluaran non karbohidrat rumahtangga 
Gambar 2 di atas menunjukkan bahwa pengeluaran non karbohidrat tertinggi yaitu pada pengeluaran bumbu (40,72\%). Pengeluaran pada bumbu yang tinggi tersebut disebabkan karena harga bumbu dapur pada daerah penelitian tergolong mahal hal ini dikarenakan wilayah penelitian yang jauh dari pasar, selain itu bumbu merupakan kebutuhan pokok dalam rumahtangga sebagai bahan untuk memasak dan memenuhi kebutuhan sehari-hari. Oleh karena itu setiap harinya dalam rumahtangga selalu membutuhkan bumbu.Sehingga dalam rumahtanggaharus mengeluarkan uang lebih banyak untuk membeli bumbu dapur. Pengeluaran tertinggi kedua yaitu pengeluaran rokok $(13,15 \%)$, harga rokok yang tinggi di daerah penelitian juga menyebabkan pengeluaran juga semakin tinggi. Hal ini menunjukkan bahwa rata-rata kepala rumahtangga di wilayah penelitian sebagian besar merokok. Pengeluaran untuk telur (12,26\%), yang menunjukkan bahwa pengeluaran untuk telur di daerah penelitian juga tinggi. Harga telur yang mahal mengakibatkan pengeluaran untuk membeli telur semakin besar. Menurut (Arida et al., 2015), masyarakat lebih dominan mengkonsumsi telur dikarenakan telur merupakan menu makanan yang paling mudah terjangkau oleh sebagian besar masyarakat dan paling mudah untuk disajikan dalam menu makanan, oleh sebab itu telur sangat digemari di kalangan masyarakat.

Penggunaan untuk Minyak sebesar (7,99\%), hal ini minyak merupakan kebutuhan pelengkap dalam kegiatan konsumsi rumahtangga, minyak digunakan untuk menyayur dan menggoreng makanan yang akan dikonsumsi. Jika tidak banyak, maka penggunaan minyak juga hanya sedikit. Pengeluaran untuk ikan $(5,62 \%)$ yang berarti bahwa pengeluaran untuk membeli ikan tidak terlalu tinggi, untuk kebutuhan ikan biasanya mencari ikan di sungai dengan cara memancing. Pengeluaran untuk sayuran sebesar $(5,47 \%)$ juga tidak terlalu tinggi, hal ini dikarenakan sayuran merupakan kebutuhan makanan yang mudah di dapat di desa Karang Jaya. Biasanya masyarakat memiliki tanaman sayuran di halaman atau di kebun belakang rumah, sehingga akan meminimalisir pengeluaran untuk membeli sayuran, pengeluaran untuk ayam sebesar $(4,71 \%)$ yang berarti bahwa masyarakat mengeluarkan sebagian pendapatannya untuk membeli ayam sebagai kebutuhan protein dalam makanan. Begitu juga dengan pengeluaran tahu $(3,27 \%)$ dan tempe $(2,78 \%)$, dimana masyarakat masih membeli tahu dan tempe untuk dikonsumsi

Pengeluaran untuk daging sebesar $(1,94 \%)$ Pengeluaran daging dalam penelitian ini sedikit, dikarenakan harga daging yang mahal menyebabkan petani jarang membeli daging, biasanya mengkonsumsi daging hanya 1 atau 2 kali dalam setahun, pengeluaran untuk buah-buahan $(1,91 \%)$ juga memiliki pengeluaran yang lebih kecil, disebabkan karena petani jarang membeli buah-buahan di toko, karena biasanya petani mengkonsumsi buah-buahan hasil tanaman sendiri seperti pisang, jambu, jeruk dan tanaman yang ada di sekitar halaman rumah. Selanjutnya yaitu pengeluaran untuk kacang kedelai $(0,19 \%)$, pengeluaran untuk kacang kedelai memiliki pengeluaran yang lebih kecil daripada pengeluaran non karbohidrat yang lain, disebabkan karena petani tidak mengkonsumsi kacang kedelai langsung, tetapi langsung mengkonsumsi bahan makanan jadi yang berasal dari bahan baku kacang kedelai seperti tahu dan tempe. sehingga pengeluaran kacang kedelai tidak terlalu tinggi.

c. Pengeluaran non pangan

Pengeluaran yang dikeluarkan selain bahan pangan merupakan pengeluaran non pangan. Pengeluaran non pangan dalam penelitian ini terdiri dari pengeluaran untuk kosmetik, biaya sekolah, keperluan pesta, PLN dan telepon, dan pengeluaran BBM. Berikut ini disajikan proporsi masing-masing pengeluaran nin pangan: 


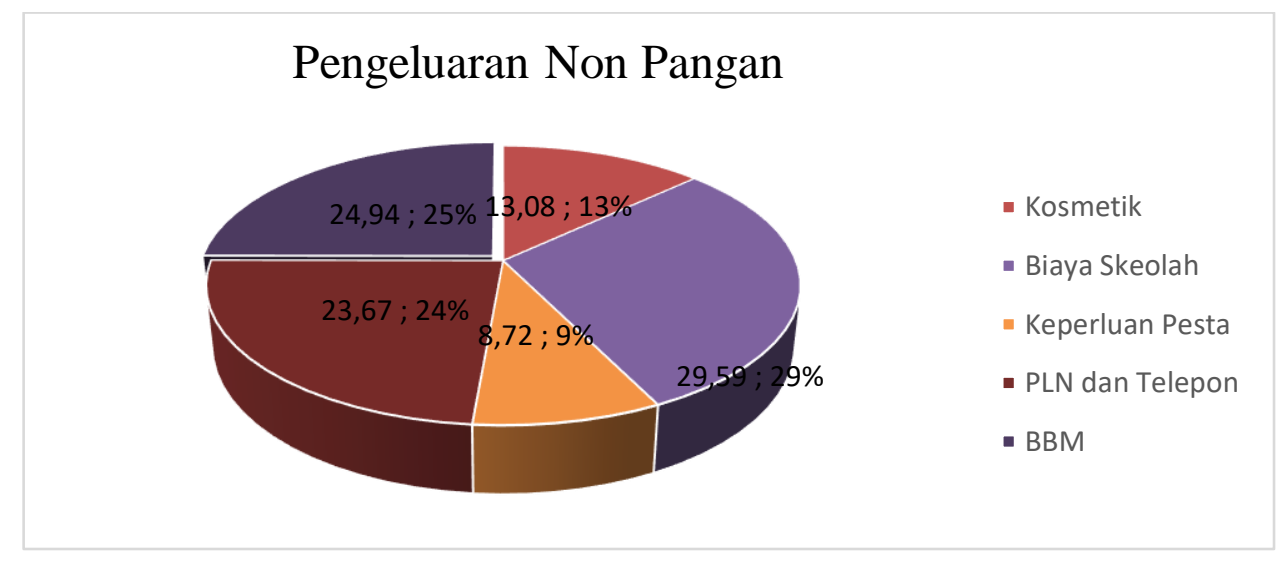

Gambar 3. Proporsi pengeluaran non pangan rumahtangga petani karet

Berdasarkan Gambar 3 di atas, menunjukkan bahwa pengeluaran non pangan tertinggi adalah biaya sekolah (29,59\%), kemudian Bahan Bakar Minyak (BBM) sebesar (24,94\%), PLN dan telvon (23,67\%), kosmetik (3,08\%), keperluan pesta $(8,72 \%)$. Hal ini berarti bahwa di Kecamatan Karang Jaya sebagian besar masyarakatnya memiliki anggota keluarga yang masih menempuh jenjang pendidikan, Hal ini dikarenakan biaya pendidikan yang juga cukup mahal. Hasil penelitian serupa (Jannah, 2018) menyatakan bahwa dalam rumahtangga yang masih memiliki jumlah anak sekolah, maka semakin bertambah pengeluaran rumahtangga yang dialokasikan untuk biaya pendidikan anak. Semakin banyak jumlah anak yang masih bersekolah, maka semakin besar pengeluaran yang akan dialokasikan untuk biaya pendidikan. Hasil tersebut juga didukung hasil penelitian (Karolina et al., 2016), menyatakan bahwa pengeluaran di bidang pendidikan yang tinggi menyebabkan tingginya biaya pendidikan selain itu ditambah dengan biaya peralatan sekolah untuk menunjang proses pembelajaran.

d. Pengeluaran Konsumsi Rumahtangga Petani Karet

Pengeluaran rumahtangga petani karet di Kecamatan Karang Jaya terdiri dari pengeluaran karbohidrat, non karbohidrat dan non pangan. Untuk lebih jelasnya dapat dilihat pada Tabel 2 sebagai berikut:

Tabel 2. Pengeluaran Rumahtangga Petani Karet

\begin{tabular}{clccc}
\hline No & \multicolumn{1}{c}{ Pengeluaran } & Jumlah (Rp) & Rata-rata (Rp) & Presentase (\%) \\
\hline 1 & Pangan Karbohidrat & 692.902 .000 & 7.293 .705 & 44.60 \\
2 & Pangan Non Karbohidrat & 392.152 .000 & 4.127 .916 & 25.06 \\
3 & Non Pangan & 511.362 .000 & 5.382 .757 & 30.34 \\
\hline & Total & 1.596 .416 .000 & 16.804 .378 & 100
\end{tabular}

Sumber: Data Primer, 2019

Rata-rata pengeluaran rumahtangga petani karet di Kecamatan Karang Jaya digunakan untuk pengeluaran karbohidrat, non karobhidrat dan non pangan. Berdasarkan Tabel 2 menunjukkan rata-rata pengeluaran pangan karbohidrat sebesar Rp. 7.293.705/tahun atau sebesar 44.60\%. Pangan non karbohidrat sebesar Rp. 4.127.916/tahun atau 25.06\% dan pengeluaran pangan sebesar Rp. 5.382.757/tahun atau sebesar $30.34 \%$. Hal ini berarti bahwa pengeluaran pangan karbohidrat memiliki pengeluaran terbesar dari pengeluaran total rumahtangga di Kecamatan Karang Jaya. Pengeluaran rumahtangga petani karet untuk karbohidrat lebih besar dari pengeluaran lainnya karena merupakan salah satu kebutuhan primer (pokok) dalam rumahtangga. Hal ini sejalan dengan penelitian (Suratinojo et al., 2014), bahwa masyarakat pada umumnya memiliki perilaku untuk mengutamakan kebutuhan yang utama dalam bertahan hidup yaitu kebutuhan makanan dan minuman 
sebagai sumber energi. Menurut (Arida et al., 2015) dalam rumahtangga apabila proporsi pengeluaran pangan lebih besar dibandingkan dengan pengeluaran non pangan maka menunjukkan bahwa rumahtangga tersebut masih belum sejahtera. Penelitian sejenis oleh (Subarna, 2012) yang menyatakan bahwa semakin tinggi persentase pengeluaran non makanan dapat mengindikasikan adanya perbaikan tingkat kesejahteraan dalam rumahtangga.

\section{Faktor-faktor Yang Mempengaruhi Pengeluaran Rumahtangga}

Pengeluaran rumahtangga di Kecamatan Karang Jaya tidak terlepas dari faktor-faktor yang mempengaruhinya, yaitu pendidikan, umur, pendapatan, Jumlah anggota keluarga dan luas lahanSecara rinci hasil analisis menggunakan regresi linier berganda dapat dilihat pada Tabel 3 sebagai berikut:

Tabel 3. Hasil Analisis Pengaruh Pengeluaran Rumahtangga Petani Karet

\begin{tabular}{llccc}
\hline No & Variabel & Koefisien Regresi & t-hitung & Signifikan \\
\hline & (Constant) & 2,617 & 3,858 & 0,000 \\
1 & Pendidikan $\left(\mathrm{X}_{1}\right)$ & $-0,010$ & $-0,390$ & 0,698 \\
2 & Umur $\left(\mathrm{X}_{2}\right)$ & $-0,089$ & $-1,779$ & 0,079 \\
3 & Pendapatan $\left(\mathrm{X}_{3}\right)$ & 0,852 & 24.098 & 0,000 \\
4 & Jumlah anggota keluarga $\left(\mathrm{X}_{4}\right)$ & 0,058 & 2.425 & 0,017 \\
5 & Luas Lahan $\left(\mathrm{X}_{5}\right)$ & 0,006 & 0,286 & 0,775 \\
\hline
\end{tabular}

Keterangan : $\alpha: 0,05 \%$

F Hitung : 141,56

R Square: 0,888

Berdasarkan Tabel Persamaan regresi yang terbangun adalah sebagai berikut:

$\mathrm{Yi}=2,617-0,010 \mathrm{X}_{1}-0,089 \mathrm{X}_{2}+0,852 \mathrm{X}_{3}+0,058 \mathrm{X}_{4}+0,006 \mathrm{X}_{5}+\mathrm{e}$

Hasil analisis pada variabel pendidikan berpengaruh negatif dan tidak signifikan terhadap pengeluaran rumahtangga. Hasil t hitung $(-0,390)<\mathrm{t}$ tabel (1.986) yang memiliki makna bahwa hipotesis yang diajukan dalam penelitian Ho diterima, yaitu tingkat pendidikan petani karet di Kecamatan Karang Jaya tidak memiliki pengaruh yang signifikan dalam pengeluaran rumahtangga. Hal ini dikarenakan bahwa yang menentukan keputusan pengeluaran dalam rumahtangga terutama dalam pengeluaran pangan didominasi oleh keputusan istri. Sesuai hasil penelitian (Rosiana \& Saskara, 2018) yang menyatakan bahwa tingkat pendidikan tidak berpengaruh secara signifikan terhadap pengeluaran konsumsi pada rumahtangga. Hasil penelitian serupa didukung juga oleh (Hildayanti, 2017) yang menunjukkan bahwa tingkat pendidikan yang ditempuh petani tidak berpengaruh terhadap pengeluaran rumahtangga, artinya pengeluaran yang dikeluarkan lebih dominan ke pengeluaran konsumsi pangan.

Hasil regresi menunjukkan bahwa umur memil iki koefisien regresi -0,089 yang negatif dan tingkat signifikan sebesar 0,079. Hal ini berarti bahwa umur berpengaruh negatif signifikan terhadap pengeluaran rumahtangga. Setiap penambahan umur sebesar 1 persen, maka pengeluaran akan turun sebesar 8 persen. Dengan kata lain bahwa semakin tua umur responden, maka pengeluaran semakin berkurang atau turun. Maka konsumsi pangan karbohidrat dan konsumsi pangan semakin berkurang seiring bertambahnya umur responden. Dalam penelitian ini $\alpha=0,05$ dengan nilai t tabel sebesar 1,986. Maka t hitung $(-1,779)<\mathrm{t}$ tabel $(1.986)$ yang berarti hipotesis Ho ditolak. Hasil penelitian ini mendukung penelitian Rosiana (2018), bahwa usia yang sudah tua memiliki kecenderungan kebutuhan yang lebih sedikit dibandingkan dengan usia ketika masih muda. Sehingga dalam hal ini akan mengurangi pengeluaran rumahtangga. Selain itu sejalan dengan pendapat Dianawati, et.al (2016), yang menyatakan bahwa tinggi nya pengeluaran konsumsi rumahtangga tidak dipengaruhi oleh umur yang semakin tua, hal ini dikarenakan stamina seseorang semakin turun. Hasil penelitian serupa juga didukung (Hildayanti, 2017) bahwa umur tidak berpengaruh terhadap pengeluaran rumahtangga petani, hal ini dikarenakan umur petani lebih diindikasikan oleh status sosial dalam masyarakat di daerah tertentu. 
Hasil analisis pendapatan berpengaruh positif dan signifikan dengan nilai t hitung sebesar $(24,098)>t$ tabel (1.986). Semakin tinggi pendapatan yang diterima oleh seorang rumahtangga maka semakin besar juga pengeluaran yang digunakan. Namun apabila petani karet memiliki keterampilan dalam mengelola pengeluaran rumahtangga untuk memenuhi kebutuhan hidupnya, maka pendapatan yang diterima akan mampu diinvestasikan/ditabung. Sejalan dengan penelitian (Mardiana et al., 2014) bahwa pola pengeluaran rumahtangga yang dikeluarkan dipengaruhi oleh tingkat pendapatan yang diperoleh. Apabila pendapatan semakin tinggi maka seseorang akan menjadi lebih konsumtif dalam mengkonsumsi barang yang berkualitas. Hasil ini juga didukung oleh penelitian (Humaidi et al., 2015) bahwa pendapatan masyarakat mempengaruhi pola pengeluaran suatu rumahtangga. Semakin tinggi pendapatan, maka proporsi pengeluaran pangan (karbohidrat dan non karbohidrat) akan berkurang secara signifikan, dan sejalan dengan penelitian (Puspitasari et al., 2019) bahwa semakin tinggi pendapatan, maka proporsi pengeluaran untuk karbohidrat, non karbohidrat dan non pangan akan meningkat.

Analisis pada variabel jumlah anggota keluarga, apabila dilihat dari hubungan jumlah anggota keluarga petani terhadap pengeluaran rumahtangga menunjukkan bahwa jumlah anggota keluarga berpengaruh positif signifikan $(0,017)$ terhadap pengeluaran rumahtangga terlihat dari hasil $t$ hitung $(2,425)>t$ tabel $(1.986)$. Hal ini berarti bahwa apabila Jumlah anggota keluargakeluarga bertambah maka pengeluaranpangan dan non pangan semakin meningkat. Sejalan dengan penelitian Purwanto, et.al (2018), menyatakan bahwa banyaknya jumlah anggota keluarga menyebabkan biaya kebutuhan hidup yang dikeluarkan semakin besar. Hasil serupa dengan penelitian (Lestari, 2016) bahwa jumlah anggota keluarga dalam satu rumah akan mempengaruhi pengeluaran konsumsi rumah tangga, hal ini dikarenakan kebutuhan rumah tangga yang semakin banyak. Menurut (Hildayanti, 2017) yang menyatakan bahwa semakin banyak jumlah anggota keluarga maka semakin besar juga pengeluaran rumahtangga petani, terutama untuk pengeluaran keperluan sehari-hari. Penelitian serupa juga didukung oleh (Jannah, 2018) yang menyatakan bahwa jumlah anggota keluarga yang ada dan tinggal dalam satu rumah menjadi tanggungan biaya hidup oleh kepala keluarga, sehingga pengeluaran untuk konsumsi pangan lebih besar karena merupakan salah satu kebutuhan primer rumahtangga.

Luas lahan dalam penelitian ini memiliki hasil regresi dengan tingkat signifikansi $(0,957)$, yang memiliki makna bahwa luas lahan tidak memiliki pengaruh dalam pengeluaran rumahtangga. Hasil analisis menunjukkan bahwa t hitung $(0,286)<\mathrm{t}$ tabel $(1.986)$, yang berarti bahwa luas lahan tidak memiliki pengaruh signifikan terhadap pengeluaran rumahtangga. Setiap kenaikan 1 persen luas lahan, tidak menambah pengeluaran rumahtangga sebanyak 0,002 , artinya seberapapun besar luas lahan yang digarap, jumlah tanaman karet yang diusahakannya tidak bertambah sehingga pendapatan tetap dan pengeluaran untuk biaya produksi luas lahan tidak megalami kenaikan.

Secara bersama-sama dilihat dari hasil regresi menunjukkan bahwa nilai $F$ hitung $(141,56)>F$ tabel $(2,47)$, yang berarti bahwa pendidikan, umur, pendapatan, jumlah anggota keluarga dan luas lahan memiliki pengaruh positif dan siginifikan terhadap pengeluaran rumahtangga petani karet di Kecamatan Karang Jaya. Nilai R Square sebesar 0,888 menerangkan bahwa $88 \%$ pengeluaran dalam rumahtangga dapat dijelaskan oleh variabel pendidikan, umur, pendapatan, jumlah anggota keluarga dan luas lahan. Sedangkan sisanya $18 \%$ ditentukan oleh variabel lain di luar model penelitian.

\section{Tingkat Kesejahteraan Rumahtangga Petani Karet}

Untuk mengetahui tingkat kesejahteraan dalam rumahtangga dapat dilihat dari beberapa kriteria tempat tinggal di wilayah penelitian. Menurut (Sitepu, 2012) kriteria yang dirumuskan BPS dalam tingkat kesejahteraan didasarkan pada konsep akses pemenuhan kebutuhan dasar. Kemampuan dalam rumahtangga diasumsikan terwakili oleh penguasaan, bahan bangunan, dan fasilitas rumah tempat tinggal dan aset dalam benda. Pada penelitian ini, 14 variabel yang diteliti berdasarkan kriteria (Statistik, 2005) yaitu jenis dinding, sumber air minum, bahan bakar yang digunakan, fasilitas sanitasi, jenis lantai, pendidikan, sumber penerangan, 
kepemilikan aset, tempat berobat, luas lantai, konsumsi daging/ayam/susu, pakaian, makan dan pendapatan. Berikut masing-masing aspek yang diteliti:

Tabel 4. KriteriaKondisi Rumahtangga Kecamatan Karang Jaya

\begin{tabular}{|c|c|c|c|c|}
\hline No & Uraian & Sangat Miskin (\%) & Miskin (\%) & Tidak Miskin (\%) \\
\hline 1 & Jenis Dinding & Bambu (0) & Kayu $(35,79)$ & Tembok $(64,21)$ \\
\hline 2 & Sumber air minum & Sungai $(29,47)$ & Sumur $(70,53)$ & PAM (0) \\
\hline 3 & Bahan Bakar & Daun-daun kering (0) & Kayu $(22,11)$ & LPG $(77,89)$ \\
\hline 4 & Fasilitas sanitasi & Tanah (0) & Sungai $(26,32)$ & Permanen $(73,68)$ \\
\hline 5 & Jenis lantai & Kayu $(15,79)$ & Ubin/semen $(68,42)$ & Keramik $(15,79)$ \\
\hline 6 & Pendidikan & Tidak sekolah (0) & $\mathrm{SD}(54)$ & SMP dan SMA (46) \\
\hline 7 & Sumber penerangan & Obor bambu (0) & Lampu ublik $(1,05)$ & PLN $(98,95)$ \\
\hline 8 & $\begin{array}{l}\text { Kepemilikan } \\
\text { aset/tabungan }\end{array}$ & Tidak punya aset $(6,32)$ & Sepeda $(0)$ & $\begin{array}{l}\text { Mobil }(8,42) \text {, motor } \\
(85,26)\end{array}$ \\
\hline 9 & Tempat berobat & $\begin{array}{l}\text { Konsumsi obat } \\
\text { tradisonal }(10,52)\end{array}$ & Polindes $(66,54)$ & $\begin{array}{l}\text { Puskesmas/Rumah } \\
\text { Sakit }(22,94)\end{array}$ \\
\hline 10 & Luas Lantai & $<8 \mathrm{M}^{2}(12,31)$ & $8 \mathrm{M}^{2}(58,87)$ & $>8 \mathrm{M}^{2}(46,56)$ \\
\hline 11 & $\begin{array}{l}\text { Konsumsi } \\
\text { Daging/ayam/susu }\end{array}$ & $\begin{array}{l}<1 \text { kali seminggu } \\
(20,84)\end{array}$ & $1 \quad$ kali seminggu & $\begin{array}{l}>1 \text { kali seminggu } \\
(27,03)\end{array}$ \\
\hline 12 & Pakaian & $<1$ kali setahun $(12,95)$ & 1 kali setahun $(46,27)$ & $\begin{array}{l}>1 \text { kali setahun } \\
(40,78)\end{array}$ \\
\hline 13 & Makan & $<1-2$ kali sehari $(2,21)$ & 1-2 kali sehari $(19,23)$ & $\begin{array}{l}>1-2 \text { kali sehari } \\
(78,56)\end{array}$ \\
\hline 14 & Pendapatan & $\begin{array}{l}<\text { Rp. } 600 \cdot 000 / \text { bulan } \\
(8,23)\end{array}$ & $\begin{array}{l}\text { Rp. 600.000/bulan } \\
(53,69)\end{array}$ & $\begin{array}{l}>\text { Rp. } 600.000 / \text { bulan } \\
(38,08)\end{array}$ \\
\hline
\end{tabular}

Sumber: Data Primer diolah, 2019

Data di atas menunjukkan keadaan rumahtangga masyarakat di Kecamatan Karang Jaya. Rata-rata masyarakat disana sebagian besar menggunakan jenis dinding tembok sebesar 64,21\%, sisanya masih menggunakan jenis dinding kayu (35,79\%).Hal ini berarti bahwa keadaan masyarakat sudah sejahtera. Sumber air minum yang digunakan menggunakan sumber dari sumur 70,53\%, hal ini berarti bahwa masyarakat telah memiliki kesadaran kesehatan dalam memilih sumber air minum yang bersih. Namun masih ada 29,47\% masyarakat yang masih menggunakan air sungai sebagai sumber air minum. Penggunaan air sungai sebagai air minum sangat mempengaruhi kesehatan tubuh masyarakat itu sendiri, hal ini karena tidak higienisnya air sungai yang sudah tercemar. Sebesar 77,89\% masyarakat telah menggunakan bahan bakar LPG untuk kebutuhan hidup sehari-hari. Hal ini berarti bahwa sebagian besar masyarakat mampu membeli LPG untuk kebutuhan bahan bakar, namun ada juga masyarakat yang menggunakan bahan bakar jenis kayu.

Sebesar 73,68\% masyarakat fasilitas sanitasi yang digunakan yaitu sanitasi permanen, hal ini berarti bahwa masyarakat telah memiliki kesadaran akan kebersihan lingkungan dan kesehatan. Namun ada juga masyarakat yang masih menggunakan fasilitas sanitasi di sungai (26,32\%), Kondisi ini akan mempengaruhi kebersihan dan kenyamanan lingkungan di sekitar desa. Jenis lantai 68,42\% telah menggunakan ubin/semen, namun masih $15,79 \%$ masyarakat yang masih menggunakan jenis lantai kayu. Pendidikan masyarakat sebesar 54\% masih SD, sedangkan yang telah menempuh pendidikan tingkat SMP dan SMA sebanyatk 46\%. Sumber penerangan rata-rata telah menggunakan PLN $(98,95 \%)$ dan 1,05\% masih ada yang menggunakan lampu ublik. Kepemilikan aset motor sebanyak $85,26 \%$. Selain itu ada yang memiliki aset mobil sebanyak $(8,42 \%)$, dan $100 \%$ kepemilikan rumah merupakan milik sendiri.Sejalan dengan penelitian (Sitepu, 2012) bahwa rumahtangga yang masih menggunakan jenis dinding kayu, sumber air minum menggunakan air sumur dan sungai sebagai fasilitas sanitasi sehari-hari termasuk kedalam kriteria rumahtangga miskin. Sedangkan untuk 
penggunaan bahan bakar yang menggunakan LPG, sumber penerangan menggunakan PLN, telah memiliki aset motor, dan memiliki rumah sendiri tidak termasuk ke dalam kriteria rumahtangga miskin.

Luas lantai masyarakat yang berkisar $8 \mathrm{M}^{2}$ sebanyak 58,87\%, untuk konsumsi daging/ayam/susu sebanyak 52,13\% masyarakat mengkonsumsi satu kali dalam seminggu. Sedangkan untuk kebutuhan makan 78,56\% masyarakat > $1-2$ kali sehari. Hal ini karena makan merupakan sumber energi bagi tubuh untuk melakukan aktifitas sehari-hari. Pembelian pakaian masyarakat di kecamatan Karang Jaya sebesar 46,27\% membeli pakaian satu kali dalam setahun. Pendapatan yang diperoleh Rp. 600.000/bulan sebesar 53,69\% orang. Sehingga masyarakat di Kecamatan Karang Jaya belum bisa dikatakan sejahtera.

Dari kriteria kondisi rumah tangga pada tabel diatas, dapat disimpulkan bahwa dari ke 14 kriteria tersebut terdapat 6 kriteria yang termasuk ke dalam kategori tidak miskin yaitu jenis dinding, bahan bakar, fasilitas sanitasi, sumber penerangan, kepemilikan aset motor dan makan. Sedangkan 8 kriteria yang termasuk ke dalam kategori miskin yaitu sumber air minum, jenis lantai, tempat berobat, luas lantai, konsumsi daging/ayam/susu, pakaian, pendapatan dan pendidikan.

\section{KESIMPULAN DAN SARAN \\ Kesimpulan}

Alokasi pengeluaran rumahtangga petani karet di Kecamatan Karang Jaya terdiri dari pengeluaran karbohidrat (44,60\%), non karbohidrat (25,06\%) dan non pangan (30,34\%). Dari ketiga pengeluaran tersebut pengeluaran karbohidrat memiliki presentase tertinggi dibandingkan dengan pengeluaran lainnya

Faktor-faktor yang mempengaruhi pengeluaran rumahtangga petani karet di Kecamatan Karang Jaya yaitu umur, jumlah anggota keluarga, dan pendapatan. Sedangkan pendidikan dan luas lahan dalam penelitian ini tidak memiliki pengaruh dalam pengeluaran rumahtangga petani karet di Kecamatan Karang Jaya. Secara bersama-sama kelima variabel bebas (pendidikan, umur, pendapatan, Jumlah anggota keluarga dan luas lahan) memiliki pengaruh terhadap pengeluaran rumahtangga.

Tingkat kesejahteraan rumah tangga di Kecamatan Karang Jaya menurut 14 kriteria dari BPS terdapat 6 kriteria yang termasuk ke dalam kategori tidak miskin yaitu jenis dinding 64,21\%, bahan bakar 77,89\%, fasilitas sanitasi 73,68\%, sumber penerangan 98,95\%, kepemilikan aset motor 85,26\% dan makan78,56\%. Sedangkan 8 kriteria yang termasuk ke dalam kategori miskin yaitu sumber air minum 70,53\%, jenis lantai $68,42 \%$, tempat berobat $66,54 \%$, luas lantai $58,87 \%$, konsumsi daging/ayam/susu 52,13\%, pakaian 46,27\%, pendapatan $53,69 \%$ dan pendidikan $54 \%$.

\section{Saran}

Perlu dibangun sebuah wadah (koperasi) yang dapat membantu petani dalam memasarkan hasil produksi untuk mendapatkan informasi harga yang terkini.

Perlu adanya program sosialisasi kepada masyarakat mengenai pola konsumsi yang bervariasi, tidak terbatas pada pangan karbohidrat saja sehingga dapat meningkatkan gizi masyarakat

Perlu adanya pengontrolan dari pemerintah daerah untuk melakukan perbaikan kondisi kriteria rumah tangga yang masih termasuk ke dalam kategori miskin.

\section{DAFTAR PUSTAKA}

Arida, A., Sofyan, \& Fadhiela, K. (2015). Analisis Ketahanan Pangan Rumah Tangga Berdasarkan Proporsi Pengeluaran Pangan Dan Konsumsi Energi. Agrisep, 16(1), 20-34. https://media.neliti.com/media/publications/13198-ID-analisis-ketahanan-pangan-rumah-tanggaberdasarkan-proporsi-pengeluaran-pangan-d.pdf

Elmanora, Muflikhati, I., \& Alfiasari. (2012). Kesejahteraan Keluarga Petani Kayu Manis. Ilmu Keluarga Dan Konsumen, 5(1), 58-66. 
Fatimah, N., \& Syamsiyah, N. (2018). Proporsi Pengeluran Rumahtangga Petani Padi Di Desa Patimban Kecamatan Pusakanagara Kabupaten Subang Jawa Barat. Jurnal Ilmiah Mahasiswa AGROINFO GALUH, 4(3), 834-841.

Hasibuan, L. S. (2016). Analisis Pola Pengeluaran Rumahtangga Miskin Di Kabupaten Simalungun. Jurnal Ekonomikawan, 16(1).

Hildayanti, S. K. (2017). Faktor-faktor Yang Mempengaruhi Pengeluaran Rumahtangga Petani Karet di Kabupaten Banyuasin Sumatera Selatan. Jurnal Ecoment Global, 2(2), 57-62.

Humaidi, E., Amin, Z., \& Suryati, N. (2015). Pola Pengeluaran Rumahtangga Petani Karet di Desa Binjai Kecamatan Muara Kelingi. Societa, IV(1), 54-58.

Illahi, N., Adry, M. roza, \& Triani, M. (2018). Analisis Determinan Pengeluaran Konsumsi Rumahtangga di Indonesia. Jurnal EcoGen, 1(549-556), 3.

Jannah, R. (2018). Analisis Alokasi Pengeluaran Rumahtangga Petani Karet di Kecamatan Bajubang Kabupaten Batanghari. Repository Universitas Jambi.

Karolina, A., Bakce, D., \& Yusri, J. (2016). Analisis Pendapatan dan Pola Konsumsi Rumahtangga Petani Kelapa di Kecamatan Mandah Kabupaten Indragiri Hilir. JOM Faperta, 3(1).

Kencana, F. T., Sukiyono, K., \& Sumantri, B. (2014). Pola Konsumsi Pangan Masyarakat Berbasis Karbohidrat di Kota Bengkulu : Aplikasi Model AIDS. Agrisep, 14(2), 229-246.

Lestari, W. P. (2016). Analisis Faktor-faktor yang Mempengaruhi Konsumsi Rumahtangga PNS Guru SD di Kecamatan Kotaanyar Kabupaten Probolinggo. Jurnal Ilmiah Mahasiswa Fakultas Ekonomi Bisnis Universitas Brawijaya, 4(2).

Mardiana, R., Abidin, Z., \& Soelaiman, A. (2014). Pendapatan dan Kesejahteraan Petani Karet Rakyat di Kecamatan Bumi Agung Kabupaten Way Kanan. JIIA, 2(239-245).

Puspitasari, M. S., Amin, Z., \& Arfandi, A. (2019). Tingkat Pendapatan dan Pola Konsumsi Petani Karet di Desa Marga Sakti Kecamatan Muara Kelingi Kabupaten Musi Rawas. Journal of Food System and Agribusiness, 3(1), 1-8.

Rosiana, W., \& Saskara, I. A. N. (2018). Faktor-Faktor Yang Mempengaruhi Pengeluaran Rumahtangga Pekerja Wakita yang Bekerja di Industri Laundry Rumahtangga di Kecamatan Denpasar Selatan. Jurnal Ekonomi Dan Bisnis, 7(11).

Sitepu, A. (2012). Karakteristik Keluarga Menurut Peringkat Kemiskinan. Jurnal Informasi, 17(1).

Statistik, B. P. (2005). Pendataan Sosial Ekonomi.

Statistik, B. P. (2019). Kecamatan Karang Jaya dalam Angka.

Statistik, B. P. (2020). Provinsi Sumatera Selatan Dalam Angka (Sumatera Selatan Province in Figures).

Subarna, T. (2012). Analisis Kemiskinan dan Pengeluaran Non-Pangan Penduduk Jawa Barat. Jurnal Bina Praja, 04(04), 243-250. https://doi.org/10.21787/jbp.04.2012.243-250

Sugesti, M. T., Abidin, Z., \& Klasum, U. (2015). Analaisis Pendapatan dan Pengeluaran Rumahtangga Petani Padi Desa Sukajawa Kecamatan Bumi Ratu Nuban Kabupaten Lampung Tengah. JIIA, 3(3), 251-259.

Supriadi, M., Nancy, C., Jahidin, M., Wibawa, R, G., \& Amypalupy, K. (2010). Laporan Akhir Studi Karakteristik Sosial Ekonomi Peremahaan Karet Rakyat Partisipatif di Kecamatan Sungai Keruh dan

Hal 82 Volume 5, Nomor 1,Tahun 2021 
May Shiska Puspita Sari \& Ira, P.: Analisis Pengeluaran dan Tingkat Kesejahteraan Rumah Tangga Petani.... Babat Toman Kabupaten Musi Banyuasin Sumatera Selatan, Kerja sama Pemerintah Daerah Musi Banyuasin dan Balai Penelitian Karet Sembawa.

Suratinojo, D., Ngangi, C. R., \& Moniaga, V. R. B. (2014). Kajian Ekonomi Rumahtangga Petani Kelapa Di Kecamatan Kauditan Kabupaten Minahasa Utara. Jurnal Ilmiah Universitas Sam Ratulangi, 4(3). 